\title{
Citizens' preferences for the conservation of agricultural genetic resources
}

\section{Eija Pouta *, Annika Tienhaara and Heini Ahtiainen}

MTT Agrifood Research Finland, Helsinki, Finland

\section{Edited by:}

Juha Kantanen, MTT Agrifood

Research Finland, Finland

Reviewed by:

Jutta Roosen, Technische

Universität München, Germany

Ann Bruce, University of

Edinburgh, UK

*Correspondence:

Eija Pouta, MTT Agrifood Research

Finland, Latokartanonkaari 9,

Fl-00790 Helsinki, Finland

e-mail: eija.pouta@mtt.fi
Evaluation of conservation policies for agricultural genetic resources (AgGR) requires information on the use and non-use values of plant varieties and animal breeds, as well as on the preferences for in situ and ex situ conservation. We conducted a choice experiment to estimate citizens' willingness to pay (WTP) for AgGR conservation programmes in Finland, and used a latent class model to identify heterogeneity in preferences among respondent groups. The findings indicate that citizens have a high interest in the conservation of native breeds and varieties, but also reveal the presence of preference heterogeneity. Five respondent groups could be identified based on latent class modeling: one implying lexicographic preferences, two with reasoned choices, one indicating uncertain support and one with a preference for the current status of conservation. The results emphasize the importance of in situ conservation of native cattle breeds and plant varieties in developing conservation policies.

Keywords: native breeds, native varieties, genetic resources, choice experiment, preference heterogeneity, valuation

\section{INTRODUCTION}

The intensification of agriculture has led to marked changes in the utilization of agricultural genetic resources (AgGR), and many previously common cultivated plant varieties as well as native animal breeds that are of interest in terms of food and agricultural production have become rare or even endangered (Drucker et al., 2001; FAO, 2007, 2010). In Finland, several native breeds, such as the Eastern and Northern Finncattle, the Kainuu Gray Sheep and the Åland Sheep, are endangered according to the FAO classification (FAO, 2007), and the majority of old Finnish crop varieties as well as the Finnish landrace pig are already extinct.

Decisions on the focus and extent of genetic resource conservation should consider both the costs and benefits of conservation. The full benefits of conserving AgGR are not revealed by markets, as the resources are either not traded in the markets or the price of agricultural products does not completely capture their value (Oldfield, 1989; Brown, 1990; Drucker et al., 2001). These market failures result in an inefficient allocation of resources, i.e., the level of conservation is too low as the full benefits are not considered. Although the importance of economic analyses has been recognized, the literature on the monetary value of genetic resources in agriculture is still relatively limited (e.g., Evenson et al., 1998; Rege and Gibson, 2003; Ahtiainen and Pouta, 2011).

Conservation policies for AgGR in Finland, as in many other European countries, are currently based on international agreements such as the Convention on Biological Diversity (1992) and the Global Plan of Action for Animal Genetic Resources (FAO, 2007). National genetic resource programmes were initiated for plants in the year 2003 and for farm animals in 2005 to strengthen the conservation of genetic resources in Finland. Although there has been some progress in putting the programmes into action, they have not been fully implemented.
This may reflect, for example, the lack of political interest in the conservation.

To evaluate conservation policies, there is a need for monetary benefit estimates that encompass both use and non-use values associated with genetic resources. Use values refer to the benefits obtained from current and future use of genetic resources in production and breeding, while non-use values are generated from the knowledge that genetic resources, e.g., certain breeds, exist and are saved for future generations. Stated preference methods, such as the discrete choice experiment (CE) method, are capable of estimating both use and non-use values in monetary terms. A choice experiment is a survey-based method whereby respondents are asked to choose between two or more discrete alternatives that are described with attributes. By varying attribute levels and including a price variable as one of the attributes, respondents' willingness to pay (WTP) for a policy alternative or attribute level is indirectly revealed based on the choices they make (e.g., Hanley et al., 2001). The CE method has been found suitable for valuing genetic resources due to its flexibility and ability to value the different traits that breeds or varieties may have. The CE method can also be used to evaluate the means of conservation in situ (live animals and plants) and ex situ (as seeds, cryopreserved embryos and other genetic material), and both plant genetic resources (PGR) and animal genetic resources (AnGR).

Previous choice experiments have focused on valuing breeds or varieties and their attributes, especially related to their use in agriculture (Birol et al., 2006; Ouma et al., 2007), and applications focusing on consumer or citizen values for AgGR are rare. Valuation studies on biodiversity have found heterogeneity in consumer preferences, and even identified lexicographic preferences toward conservation (Hanley et al., 1995; Sælensminde, 
2006). Lexicographic preferences imply that people are unwilling to accept any trade-offs for changes in environmental goods, such as biodiversity, and may arise when an individual believes that the environment should be protected without regard to the costs. In the context of AgGR, preference heterogeneity has mainly been studied among farmers (e.g., Ouma et al., 2007; Omondi et al., 2008; Roessler et al., 2008), and there have been only few empirical studies of heterogeneity of citizen preferences (Zander et al., 2013) or lexicographic preferences.

In this paper, we present the results of a choice experiment conducted to estimate the benefits of genetic resource conservation programmes in Finland. We tested the effect of in situ and ex situ conservation on citizens' choices between programmes. We also analyzed whether plant varieties and animal breeds are perceived as equally valuable by citizens. As heterogeneity in the preferences for the conservation of AgGR is likely, we tested for the existence of citizen segments that place different values on the conservation of genetic resources.

We expected that AgGR would be rather unfamiliar to some of the respondents of the valuation survey. However, in valuation surveys, respondents are assumed to make "informed" choices when responding to value elicitation questions (e.g., Blomquist and Whitehead, 1998). To obtain informed choices that produce valid estimates of WTP, surveys need to provide a sufficient amount of neutral information on the environmental good while avoiding information overload. Providing more information on the quality (characteristics and services) of an environmental good can increase the stated WTP, have no effect, or in some cases reduce WTP (Blomquist and Whitehead, 1998).

There is a substantial body of literature on the effects of information and respondent effort in contingent valuation studies (e.g., Cameron and Englin, 1997; Blomquist and Whitehead, 1998; Berrens et al., 2004), and some choice experiment studies have also examined the issue, mainly focusing on respondent effort (Hu et al., 2009; Vista et al., 2009). Hu et al. (2009) used data from a choice experiment concerning genetically modified food to simultaneously model voluntary information access and product choices. They found that information was accessed rather infrequently, and that those who held critical views on GM food accessed information more often. There were interlinkages between information access and choices, but they were complex and varied between individuals. Vista et al. (2009) examined the effect of time spent on attribute information, choice questions or completing the survey, finding no significant effects on parameter estimates.

Here, we were particularly interested in examining how the use of information differs between respondent segments. In the survey, respondents had the opportunity to obtain additional information on genetic resources by accessing a hyperlink to a web page. The Internet survey allowed us to measure whether the respondents accessed the additional information and how much time they used to read it. Offering the opportunity for voluntary access to information instead of using different information treatments for split samples has the advantage of not assuming that respondents read all the information that is provided (Hu et al., 2009). Furthermore, we tested the effects of response certainty and self-perceived carefulness in filling the survey as sources of preference heterogeneity.

The rest of the paper is organized as follows. Section Materials and Methods introduces the data and statistical models used in the analysis. Results are presented in section Results, and section Discussion and Conclusions provides discussion and conclusions.

\section{MATERIALS AND METHODS DATA COLLECTION}

The survey data were collected using an Internet survey during the summer of 2011. The sample was drawn from the Internet panel of a private survey company, Taloustutkimus, which comprises 30,000 respondents who have been recruited to the panel using random sampling to represent the population (Taloustutkimus, 2013). After a pilot survey of 138 people, a random sample of 6200 respondents was selected, of which 2426 completed parts of the survey and 1495 completed the survey entirely. These numbers correspond to response rates of 39 and $24 \%$, respectively. Based on the socio-demographic variables, the data represented the population rather well (Table $\mathbf{1}$ ).

\section{SURVEY DESIGN}

In the first section, the survey introduced the most common Finnish native animal breeds and plant varieties by explaining what landraces are and giving examples. After asking the respondents about their familiarity with PGR and AnGR, all respondents were offered a short piece of information on the conservation of these breeds and varieties. Next, the respondents were given the opportunity to obtain further information by clicking on two hyperlinks, one for PGR and the other for AnGR. Providing voluntary access to additional information made it possible to identify those respondents who accessed the information, and the time spent on the information page was also recorded $(\mathrm{Hu}$ et al., 2009). The additional information provided in our survey included motives for conservation, descriptions of the in situ and ex situ conservation methods and facts about the sustainable use of genetic resources. After several questions concerning perceptions of genetic resources, the survey proceeded to the choice experiment.

Table 1 | Descriptive statistics $(n=1608)$.

\begin{tabular}{|c|c|c|}
\hline & $\begin{array}{l}\text { In the } \\
\text { data }\end{array}$ & $\begin{array}{l}\text { In the } \\
\text { population }\end{array}$ \\
\hline Proportion of females, \% & 48 & 51 \\
\hline Mean age, years & 52 & 47 \\
\hline $\begin{array}{l}\text { Proportion of people with a higher educational } \\
\text { level, \% }\end{array}$ & 24 & 23 \\
\hline $\begin{array}{l}\text { Proportion of people living in households with a } \\
\text { gross income under } € 40,000, \%\end{array}$ & 43 & 53 \\
\hline $\begin{array}{l}\text { Proportion of people with children ( }<18 \text { years) in } \\
\text { the family, \% }\end{array}$ & 35 & 40 \\
\hline Proportion of people living in South Finland, \% & 40 & 41 \\
\hline
\end{tabular}

a Statistics Finland 2010, www.stat.fi. 
The choice experiment was framed by telling respondents that the conservation of native plant varieties and animal breeds is not yet comprehensive in Finland. The survey presented a programme that would conserve the majority of the varieties and breeds on farms and in gene banks. The operation of gene banks would be extended to missing plants and varieties, and conservation on farms would be enhanced by developing the support provided to farmers for conservation activities. Furthermore, those who are using native varieties in gardens were stated to be supported monetarily and by providing guidance.

The survey explained that the conservation programme would be financed with an increase in income tax between the years 2012 and 2021, and that depending on the extent of the programme, the cost to taxpayers would vary, but all taxpayers would participate in financing the programme. The conservation measures (attributes) of the alternative programmes were illustrated to the respondents using a table.

Table 2 presents the attributes together with their descriptions and levels. The first attribute level is always the level specified in the status quo alternative (current state). The attributes included conservation measures of both plant varieties and animal breeds in gene banks and farms. Instead of having a separate attribute for each native breed, only one attribute for breeds in gene banks and one on farms was included to have the same number of attributes for varieties and breeds, and to ease the cognitive burden of the respondents. The native breeds in gene banks attribute had eight levels and native breeds on farms nine levels, including the status quo attribute level.

After introducing the attributes, the respondents were presented with six choice tasks. Each choice task included three alternatives: the status quo alternative, described as maintaining the current situation, and two policy alternatives describing an improved level of conservation compared to the current level. Each alternative was described with five conservation attributes, their levels and the cost attribute. The status quo alternative was uniform across choice tasks. An example of a choice task is shown in Table 3.

We employed an efficient experimental design to allocate the attribute levels to the choice tasks in the choice experiment survey. Efficient designs aim to generate parameter estimates with standard errors that are as low as possible, and thus produce the maximum information from each choice situation (e.g., Rose and Bliemer, 2009). The generation of efficient designs requires the specification of priors for the parameter estimates. In the pilot survey, we employed zero priors in the design, and used the parameter estimates obtained in the pilot study to construct the final experimental design. In the final study, we employed a Bayesian D-efficient design using Ngene (v. 1.0.2), taking 500 Halton draws for the prior parameter distributions. Bayesian designs take into account the uncertainty related to the parameter priors. Instead of fixed priors, they make use of random priors by specifying a mean and standard deviation for the prior.

Table 2 | Attributes of conservation programmes and their levels.

\begin{tabular}{|c|c|c|c|}
\hline Attribute & Description & Current state & Levels (unit) \\
\hline $\begin{array}{l}\text { Native food plant varieties in } \\
\text { gene banks }\end{array}$ & $\begin{array}{l}\text { Native food plants are stored in a gene } \\
\text { bank, either as seeds or plant parts. }\end{array}$ & $\begin{array}{l}\text { The gene bank contains seeds from about } 300 \\
\text { landrace varieties. Plants that are added } \\
\text { vegetatively (e.g., berry and apple varieties) } \\
\text { are missing. }\end{array}$ & $\begin{array}{l}300,400,500 \\
\text { (number of plants) }\end{array}$ \\
\hline $\begin{array}{l}\text { Farms growing native food } \\
\text { plants }\end{array}$ & $\begin{array}{l}\text { Farmers and hobby gardeners } \\
\text { cultivate native food plants on farms } \\
\text { or in gardens. }\end{array}$ & $\begin{array}{l}\text { Seven farms grow seeds of native food plants } \\
\text { with agri-environmental support. Other } \\
\text { activities than growing seeds are not } \\
\text { supported. }\end{array}$ & $\begin{array}{l}\text { 7, 500, } 1000 \\
\text { (number of farms) }\end{array}$ \\
\hline $\begin{array}{l}\text { Native ornamental plant } \\
\text { varieties mapped and in gene } \\
\text { banks }\end{array}$ & $\begin{array}{l}\text { Scientists identify and register native } \\
\text { ornamental plants. Varieties are } \\
\text { preserved in a gene bank, either as } \\
\text { seeds or plant parts. }\end{array}$ & $\begin{array}{l}\text { Only a small proportion of the native } \\
\text { ornamental plants are known. Storage in the } \\
\text { official gene bank is not provided. }\end{array}$ & $\begin{array}{l}\text { small proportion, about half, } \\
\text { majority } \\
\text { (proportion of plants) }\end{array}$ \\
\hline Native breeds in gene banks & $\begin{array}{l}\text { Landrace breeds are kept in a gene } \\
\text { bank as gametes and embryos. }\end{array}$ & $\begin{array}{l}\text { The gene bank contains Western, Eastern and } \\
\text { Northern Finncattle, as well as Finn-, Alland and } \\
\text { Kainuu sheep. Native chicken, goat and horse } \\
\text { breeds are missing from the gene bank. }\end{array}$ & $\begin{array}{l}3 \text { cattle breeds and } 3 \text { sheep } \\
\text { breeds (status quo level), + } \\
\text { all combinations of goat, } \\
\text { horse and chicken breeds }\end{array}$ \\
\hline Native breeds on farms & $\begin{array}{l}\text { Native breeds are kept on farms in } \\
\text { their natural environment. A breed is } \\
\text { considered to be endangered if the } \\
\text { number of females is less than } 1000 \text {. }\end{array}$ & $\begin{array}{l}\text { Farms secure goat, horse and chicken breeds, } \\
\text { Finnish sheep and Western Finncattle. Eastern } \\
\text { and Northern Finncattle, as well as Alland and } \\
\text { Kainuu sheep, are endangered. }\end{array}$ & $\begin{array}{l}1 \text { cattle breed, } 1 \text { sheep } \\
\text { breed, goat, horse and } \\
\text { chicken (status quo level), + } \\
\text { all combinations of } \\
\text { additional } 1-2 \text { cattle and } \\
\text { sheep breeds }\end{array}$ \\
\hline Cost & $\begin{array}{l}\text { Cost for taxpayers, } \\
€ / \text { year during 2012-2021. }\end{array}$ & No additional costs. & $\begin{array}{l}0,5,20,40,80,100,150 \\
300(€)\end{array}$ \\
\hline
\end{tabular}




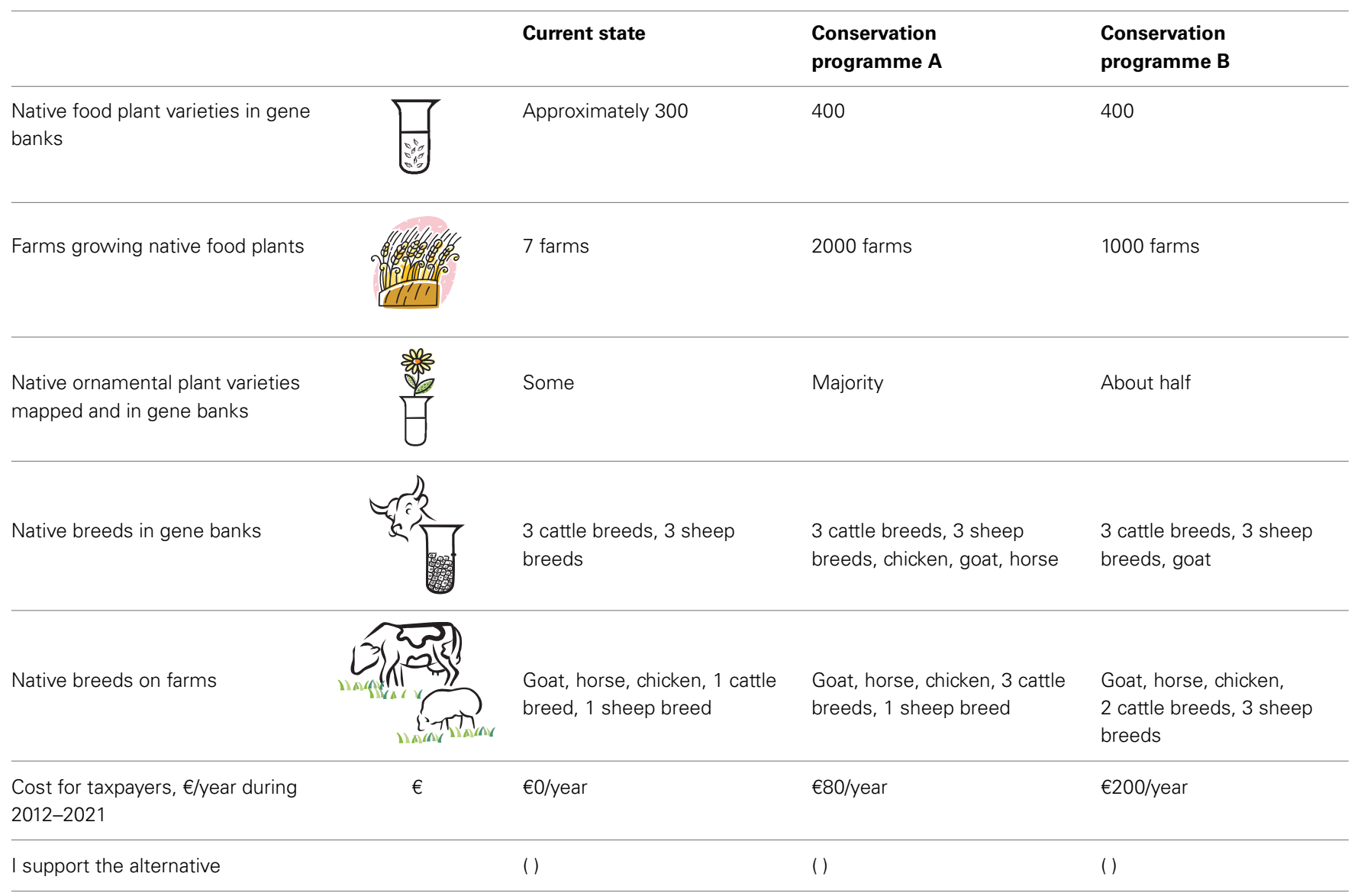

In the design phase, animal breeds in gene banks and on farms were treated as separate attributes, but were later combined to the "Native breeds in gene banks" and the "Native breeds on farms" attributes in the choice tasks presented to the respondents. Bayesian priors were employed for the chicken attribute and the number of cattle breeds on the farm attribute, and fixed priors for all other attributes. We generated 180 choice tasks, blocking them into 30 subsets, which resulted in six choice situations presented for each respondent. The final design had a D-error of 0.002 .

\section{STATISTICAL MODELS}

The choices between environmental programmes were originally modeled with a conditional logit model (also called a multinomial logit model) (McFadden, 1974). The conditional logit, however, assumes a similar preference structure for all respondents, which implies that they have similar tastes for the attributes of conservation. In this study, we were particularly interested in defining heterogeneous citizen segments, which have a similar preference structure within each segment. One approach that allows this heterogeneity is the latent class model (Boxall and Adamowicz, 2002), which has frequently also been applied in choice experiment models of environmental conservation programmes (e.g., Garrod et al., 2012; Grammatikopoulou et al., 2012). In the latent class model, preferences are assumed to be homogeneous in each segment, but to vary between the segments.
In the modeling, price was treated as a continuous variable and the other attributes were effects-coded, implying that the parameters will sum to zero over the categories of the nominal variable concerned. The status quo attribute levels were thus included in the model, and could obtain either negative or positive coefficients depending on their effect on respondent's utility. Alternative-specific constants (ASC) were included for all alternatives in order to allow systematic choice tendencies not explained with the parameters describing the attributes.

Heterogeneity was statistically included in the latent class model by simultaneously dividing individuals into behavioral groups or latent segments, and estimating a choice model for each of these classes. The estimation was carried out by assuming first one class, then two classes, three classes and so forth. In each step, the explanatory power of the model was assessed to decide on the optimal number of classes. For this purpose, we used the Bayesian information criterion (BIC) and Akaike information criterion (AIC), which are log-likelihood scores with correction factors for the number of observations and the number of parameters. The latent class model also enables the calculation of the WTP for the attributes for each citizen segment.

The relationship between the individual characteristics and the latent classes was examined a posteriori of the actual estimation of the latent class model in order to describe the heterogeneous citizen segments. Thus, the segments were formed solely based 
on the conservation program choices. The membership in the most probable segment was regressed using a logistic regression to characterize each class compared to the rest of the respondents. The explanatory variables for the class memberships included respondents' socioeconomic characteristics, perceived values and responsibilities, use of provided information, response certainty and self-reported perception of the carefulness of completing the survey. The independent variables in the logistic regression models and their descriptive statistics are presented in Table 4.

\section{RESULTS}

In $24 \%$ of the choice sets, the respondents chose the status quo option, i.e., the current state without any additional program to conserve AgGR. The probability of choosing one of the two alternative conservation programs varied between $46 \%$ for the lowest cost level of $€ 5$ and $28 \%$ for the highest cost level of $€ 300$.

Table 5 presents the conditional logit model results for the choice of the conservation programme. As expected, an increase in the programme cost negatively affected the probability of choosing it. Turning to consider the genetic resource attributes, the number of food plants in the gene bank was not statistically significant. All other attributes were significant in determining respondents' choices. A higher number of farms growing native plant varieties increased the choice probability. The larger the number of ornamental plants to be mapped and conserved in gene banks, the more probable it was that the respondent would choose the programme. Conserving native breeds of Finnish goats, horses and chickens in the gene bank all increased the support for the programme. The effect was highest for horse, followed by chicken and goat. The guaranteed existence of cattle breeds on farms had a positive and significant effect on choice. As expected, the effect was greater if the number of conserved cattle breeds was three instead of two. This was also the case with sheep breeds, although the conservation of two breeds did not have a positive effect on choice compared with the status quo of one conserved breed.

The alternative specific constants (ASC) capture the tendency to choose one of the alternatives which is not explained by

Table 4 | Variables in the logistic regression models.

\begin{tabular}{|c|c|c|c|c|c|}
\hline Characteristic & Description & Mean & $\begin{array}{l}\text { Standard } \\
\text { deviation }\end{array}$ & Min & Max \\
\hline Female & 1 if the respondent is female, if male & 0.49 & 0.50 & 0 & 1 \\
\hline Year of birth & Respondents year of birth, continuous & 1960 & 15 & 1931 & 1992 \\
\hline High income & 1 if household income is over $€ 50,000$ per year, 0 otherwise & 0.45 & 0.49 & 0 & 1 \\
\hline High education & 1 if respondents education level is university education, 0 otherwise & 0.24 & 0.46 & 0 & 1 \\
\hline Eastern Finnish & 1 if respondents lives in Eastern Finland, 0 otherwise & 0.11 & 0.32 & 0 & 1 \\
\hline Childhood in city & 1 if respondent spent his/her childhood in a city, 0 otherwise & 0.41 & 0.49 & 0 & 1 \\
\hline Certainty & $\begin{array}{l}\text { Mean of respondent's certainty in the conservation programme choices, } \\
\text { on a scale of } 10 \text { completely certain }-1 \text { not at all certain. }\end{array}$ & 6.85 & 2.23 & 1 & 10 \\
\hline Agri-environmental attitude & $\begin{array}{l}\text { Importance of environmental issues in agriculture, mean of nine } \\
\text { measures on scales from } 1 \text { to } 4\end{array}$ & 3.26 & 0.44 & 1 & 4 \\
\hline $\begin{array}{l}\text { Relative importance of } \\
\text { preserving AgGR }\end{array}$ & $\begin{array}{l}\text { The importance of preserving native breeds and varieties relative to other } \\
\text { environmental protection measures, } \\
1 \text { if both equally important, } \\
>1 \text { if preserving native breeds and varieties more important, } \\
<1 \text { if other environmental protection measures more important }\end{array}$ & 0.94 & 0.16 & 0.36 & 1.66 \\
\hline Existence value & $\begin{array}{l}\text { Factor score based on } 8 \text { measures of the importance of existence values, } \\
\text { continuous }\end{array}$ & 0.00 & 1.00 & -4.38 & 2.39 \\
\hline Use values & $\begin{array}{l}\text { Factor score based on } 8 \text { measures of the importance of use values, } \\
\text { continuous }\end{array}$ & 0.00 & 1.00 & -3.78 & 2.62 \\
\hline Citizen responsibility & $\begin{array}{l}\text { Factor score based on } 9 \text { measures of stakeholder responsibilities in } \\
\text { conservation }^{*}\end{array}$ & 0.00 & 1.00 & -3.38 & 2.30 \\
\hline Consumer responsibility & $\begin{array}{l}\text { Factor score based on } 9 \text { measures of stakeholder responsibilities in } \\
\text { conservation }^{*}\end{array}$ & 0.00 & 1.00 & -5.27 & 2.01 \\
\hline Farmer responsibility & $\begin{array}{l}\text { Factor score based on } 9 \text { measures of stakeholder responsibilities in } \\
\text { conservation }^{*}\end{array}$ & 0.00 & 1.00 & -3.12 & 2.88 \\
\hline Familiarity of products & Familiarity of AgGR products, mean of 10 measures on scales from 1 to 3 & 2.03 & 0.42 & 1 & 3 \\
\hline Info use (animals) $>0.5 \mathrm{~min}$ & $\begin{array}{l}1 \text { if respondent used more than } 30 \mathrm{~s} \text { for additional information about } \\
\text { breeds, } 0 \text { otherwise }\end{array}$ & 0.33 & 0.47 & 0 & 1 \\
\hline Info use (plants) $>0.5 \mathrm{~min}$ & $\begin{array}{l}1 \text { if respondent used more than } 30 \mathrm{~s} \text { for additional information about } \\
\text { varieties, } 0 \text { otherwise }\end{array}$ & 0.35 & 0.48 & 0 & 1 \\
\hline Hasty response & 1 if respondent evaluated his/her response as hasty, 0 if careful & 0.05 & 0.22 & 0 & 1 \\
\hline
\end{tabular}

*Detailed description of these variables can be found in Tienhaara et al. (2014). 
Table 5 | Conditional logit (CL) model results.

\begin{tabular}{|c|c|c|}
\hline Variable & Coefficient & Wald $p$-value \\
\hline ASC1 (SQ) & $-0.263^{* * *}$ & 0.000 \\
\hline ASC2 & $0.291^{* * *}$ & \\
\hline ASC3 & -0.028 & \\
\hline Cost & $-0.005 * * *$ & 0.000 \\
\hline 300 plants in bank (SQ) & 0.002 & 1.000 \\
\hline 400 plants in bank & -0.002 & \\
\hline 500 plants in bank & 0.000 & \\
\hline 7 plants on farms (SQ) & $-0.199 * * *$ & 0.000 \\
\hline 500 plants on farms & $0.075 * * *$ & \\
\hline 1000 plants on farms & $0.124 * * *$ & \\
\hline Ornamental plants in bank (SQ) & $-0.057^{* *}$ & 0.008 \\
\hline Ornamental plants in bank L2 & -0.004 & \\
\hline Ornamental plants in bank L3 & $0.061 * * *$ & \\
\hline Goats (SQ) & $-0.039 * * *$ & 0.005 \\
\hline Goats in bank & $0.039 * * *$ & \\
\hline Horses (SQ) & $-0.075^{* * *}$ & 0.000 \\
\hline Horses in bank & $0.075 * * *$ & \\
\hline Chickens (SQ) & $-0.047^{* * *}$ & 0.001 \\
\hline Chickens in bank & $0.047 * * *$ & \\
\hline 1 cattle breed on farms (SQ) & $-0.114 * * *$ & 0.000 \\
\hline 2 cattle breeds on farms & 0.025 & \\
\hline 3 cattle breeds on farms & $0.089 * * *$ & \\
\hline 1 sheep breed on farms (SQ) & 0.020 & 0.027 \\
\hline 2 sheep breeds on farms & $-0.052 * * *$ & \\
\hline 3 sheep breeds on farms & 0.032 & \\
\hline No. of respondents & 1608 & \\
\hline No. of observations & 9484 & \\
\hline Correct predictions \% & 48 & \\
\hline $\mathrm{R}^{2}$ & 0.04 & \\
\hline
\end{tabular}

z-test: ${ }^{* *}$ 99\% significance level; ${ }^{* *}$ 95\% significance level.

$S Q$, attribute level in the status quo alternative.

the attributes. The negative ASC1 (SQ) coefficient showed the reluctance to choose the status quo alternative regardless of the attribute levels in the policy alternatives. Furthermore, the ASC2 and ASC3 coefficients differed unexpectedly in sign and significance. The positive coefficient for ASC2 and negative for ASC3 indicated that the conservation programme that was presented first received more support. This was surprising, as the programmes were not presented in a specific order in the survey. The model predicted $48 \%$ of the choices right, clearly exceeding the probability of correct random choices of $33 \%$, leading to a relatively weak goodness of fit.

The homogeneity of preferences was tested in the estimation of the latent class models. Based on the AIC and BIC, the estimation process showed that a model of five citizen clusters provided the best fit of the data. Table 6 presents the latent class model results with the cluster names, and the logit model for the membership of each cluster is presented in Table 7 .

The latent class model showed that although preferences for some attributes, such as conserving goat and chicken breeds in gene banks and cattle breeds on farms, did not differ significantly between clusters, there was significant heterogeneity in preferences for most of the attributes. The first class, named as "conservationists," comprised $27 \%$ of the respondents. They did not take the personal cost of the conservation programme into account in their decision process, as the coefficient of the cost variable was not significant. Instead, almost all the conservation attributes had significant and positive signs. Contrary to other clusters, most plant-related attributes were significant for conservationists. They also valued the conservation of ornamental plants. Table 5 also shows that this cluster perceived higher use and existence values from genetic resource conservation than respondents in other segments, and also higher than average certainty in their responses to the choice tasks. This class contained more men than women and considered the conservation not to be a responsibility of farmers. For this cluster we also tested the effect gardening as a hobby, but it did not turn out to be significant. Thus, it seems that these respondents did not support the program because of the possible private good aspect of measures to support native varieties in gardens.

The second cluster, covering $26 \%$ of the respondents, was named as "bid-sensitive animal conservers." This group had a higher tendency to choose the improvement programmes compared to the status quo. The coefficient of the bid was significant and the second smallest of all clusters. In this cluster, the emphasis of preferences was on the conservation of animal breeds. The conservation of plant varieties in gene banks was even valued negatively. These respondents perceived more often than average that citizens and consumers should be responsible for the conservation of genetic resources. They also had positive agrienvironmental attitudes. Furthermore, the respondents in this cluster used more than the average time to familiarize themselves with the information available in the survey concerning PGR, and they were slightly younger than the average respondent.

A confusing aspect in the third cluster was the large difference between the ASC for the two conservation programmes. This group, comprising $17 \%$ of the respondents, had a considerably greater tendency to choose conservation programme A rather than B or the status quo, although this could not be explained by the experimental design and attribute levels. The bid variable followed expectations, but for the other attributes, only plants on farms and the class-independent variables were significant. The logistic regression revealed that members of this cluster were older and had a lower income, and they emphasized the responsibility of citizens in conservation. Geographically, this cluster had more members who lived in Eastern Finland. The respondents in this group were relatively uncertain of their preferences, used the additional information less, and responded, according to their self-evaluation, less carefully than other respondents. As there were random tendencies in their support for a programme (ASC), but they still preferred an increase in several conservation attributes, they were named as "uncertain supporters."

The fourth class, with $17 \%$ of respondents, clearly preferred the status quo option, as the ASC for the programme options were negative. The coefficient of the bid variable was not significant. Among these "status quo preferers," the choice was consistent with their negative attitudes, as the relative importance of AgGR was low, as well as the perceived existence and use values. Citizens 
Table 6 | Latent class models for conservation programme choice.

\begin{tabular}{|c|c|c|c|c|c|c|c|}
\hline & Class 1 & Class 2 & Class 3 & Class 4 & Class 5 & Overall & \\
\hline Pseudo $\mathrm{R}^{2}$ & 0.131 & 0.288 & 0.019 & 0.015 & 0.472 & 0.559 & \\
\hline Class size & 0.27 & 0.26 & 0.17 & 0.17 & 0.13 & & \\
\hline Class names & Conserva-tionists & $\begin{array}{c}\text { Bid-sensitive } \\
\text { animal } \\
\text { conservers }\end{array}$ & $\begin{array}{l}\text { Uncertain } \\
\text { supporters }\end{array}$ & $\begin{array}{c}\text { Status quo } \\
\text { preferers }\end{array}$ & $\begin{array}{c}\text { Bid } \\
\text { sensitives }\end{array}$ & $\begin{array}{l}\text { Wald } \\
p \text {-value }\end{array}$ & $\begin{array}{c}\text { Wald (=) } \\
p \text {-value }\end{array}$ \\
\hline Attributes & \multicolumn{7}{|c|}{ Coefficients and significance levels } \\
\hline ASC 1 (SQ) & $-0.990 * * *$ & $-2.937^{* * *}$ & $-0.841^{* * *}$ & $1.668 * * *$ & $-0.554^{* *}$ & 0.000 & 0.000 \\
\hline ASC 2 & $0.332 * * *$ & $1.499 * * *$ & $1.757 * * *$ & $-0.414 * *$ & $0.478 * * *$ & & \\
\hline ASC 3 & $0.658 * * *$ & $1.438 * * *$ & $-0.916^{* * *}$ & $-1.254^{* * *}$ & 0.076 & & \\
\hline Cost & 0.000 & $-0.018 * * *$ & $-0.003^{*}$ & -0.001 & $-0.041 * * *$ & 0.000 & 0.000 \\
\hline 300 plants in bank (SQ) & $-0.162 * * *$ & $0.138 * *$ & 0.018 & $0.412 * *$ & $-0.322^{* * *}$ & 0.003 & 0.001 \\
\hline 400 plants in bank & 0.025 & -0.007 & 0.078 & -0.166 & $0.225^{*}$ & & \\
\hline 500 plants in bank & $0.137 * *$ & $-0.131^{*}$ & -0.096 & -0.245 & 0.097 & & \\
\hline 7 plants on farms (SQ) & $-0.621 * * *$ & $-0.120^{*}$ & $-0.261 * *$ & -0.006 & -0.169 & 0.000 & 0.000 \\
\hline 500 plants on farms & $0.125^{* *}$ & $0.208 * * *$ & $0.237^{*}$ & 0.003 & 0.104 & & \\
\hline 1000 plants on farms & $0.496 * * *$ & -0.088 & 0.024 & 0.003 & 0.065 & & \\
\hline Ornamental plants in bank (SQ) & $-0.462 * * *$ & 0.015 & 0.116 & -0.004 & $-0.332 * *$ & 0.000 & 0.000 \\
\hline Ornamental plants in bank L2 & $0.158 * * *$ & 0.002 & 0.023 & -0.053 & 0.16 & & \\
\hline Ornamental plants in bank L3 & $0.304 * * *$ & -0.017 & -0.139 & 0.057 & 0.172 & & \\
\hline Goats (SQ) & $-0.063^{* * *}$ & $-0.063^{* * *}$ & $-0.063^{* * *}$ & $-0.063^{* * *}$ & $-0.063^{* * *}$ & 0.001 & C.i. \\
\hline Goats in bank & $0.063^{* * *}$ & $0.063 * * *$ & $0.063^{* * *}$ & $0.063 * * *$ & $0.063 * * *$ & & \\
\hline Horses (SQ) & $-0.152 * * *$ & $-0.128 * * *$ & -0.075 & $0.447 * * *$ & $-0.256^{* * *}$ & 0.000 & 0.000 \\
\hline Horses in bank & $0.152 * * *$ & $0.128 * * *$ & 0.075 & $-0.447^{* * *}$ & $0.256^{* * *}$ & & \\
\hline Chickens (SQ) & $-0.062^{* * *}$ & $-0.062 * * *$ & $-0.062 * * *$ & $-0.062 * * *$ & $-0.062 * * *$ & 0.001 & C.i. \\
\hline Chickens in bank & $0.062 * * *$ & $0.062^{* * *}$ & $0.062 * * *$ & $0.062 * * *$ & $0.062 * * *$ & & \\
\hline 1 cattle breed on farms (SQ) & $-0.144 * * *$ & $-0.144 * * *$ & $-0.144 * * *$ & $-0.144 * * *$ & $-0.144 * * *$ & 0.000 & C.i. \\
\hline 2 cattle breeds on farms & 0.034 & 0.034 & 0.034 & 0.034 & 0.034 & & \\
\hline 3 cattle breeds on farms & $0.110 * * *$ & $0.110 * * *$ & $0.110 * * *$ & $0.110 * * *$ & $0.110 * * *$ & & \\
\hline 1 Sheep breed on farms (SQ) & $-0.213 * * *$ & 0.046 & -0.036 & $0.581^{* * *}$ & $-0.245^{* *}$ & 0.000 & 0.001 \\
\hline 2 Sheep breeds on farms & 0.056 & -0.04 & -0.156 & -0.282 & 0.116 & & \\
\hline 3 Sheep breeds on farms & $0.157^{* * *}$ & -0.007 & 0.192 & -0.300 & 0.128 & & \\
\hline No. of respondents & 1608 & & & & & & \\
\hline No. of observations & 9484 & & & & & & \\
\hline Correct predictions \% & 85 & & & & & & \\
\hline
\end{tabular}

z-test: ${ }^{* * *} 99 \%$ significance level; ${ }^{* *} 95 \%$ significance level; ${ }^{*} 90 \%$ significance level.

SQ, attribute level in the status quo alternative.

C.i., class independent.

and consumers were less frequently seen as those responsible for conservation; instead, it was perceived as a responsibility of the farmers. This class was characterized by an older age, lower educational level and growing up on a farm.

The fifth class of respondents (13\%), named as "bid sensitives," were the most sensitive to the cost of the programme of all groups. Nevertheless, the ASC revealed that they were interested in conservation, and almost all conservation attributes had significant coefficients. Among these respondents, particularly the ex situ conservation of Finnhorse positively affected their choices. In this class, the conservation of genetic resources was not seen as a responsibility of citizens or consumers. The logit model for this group showed that they evaluated themselves as careful respondents but felt somewhat uncertain of their choices. They were younger than average and less familiar with products from traditional breeds and varieties.

WTP for different attributes was calculated based on the conditional logit model and the latent class model for those classes for which the cost coefficient was significant (Table 8). WTPs based on the conditional logit model indicated that plants on farms, cattle breeds and horses were most highly valued. In general, there was substantial variation in WTPs between the classes. In class 3, WTPs were higher due to the low importance of the cost attribute.

\section{DISCUSSION AND CONCLUSIONS}

The results of a choice experiment concerning agricultural genetic resource policies showed that citizens are interested in 
Table 7 | Logistic regression models profiling consumer classes.

\begin{tabular}{|c|c|c|c|c|c|}
\hline \multirow{2}{*}{$\begin{array}{l}\text { Class } \\
\text { Variable }\end{array}$} & Class 1 & Class 2 & Class 3 & Class 4 & Class 5 \\
\hline & \multicolumn{5}{|c|}{ Coefficients and significance levels } \\
\hline Constant & $-2.76 * * *$ & $-43.31 * * *$ & $48.77 * * *$ & $39.90 * *$ & $-29.46^{* *}$ \\
\hline Female & $-0.46 * * *$ & & & & \\
\hline Year of birth & & $0.02 * * *$ & $-0.02 * * *$ & $-0.02 * *$ & $0.02 *$ \\
\hline High income & & & $-0.39 * *$ & & \\
\hline High education & & & & $-0.72 * * *$ & \\
\hline Eastern Finnish & & & $0.40 *$ & & \\
\hline Childhood in city & & & & $-0.68 * *$ & \\
\hline Certainty & $0.12 * * *$ & & $-0.09 * *$ & & $-0.08 * *$ \\
\hline $\begin{array}{l}\text { Agri- } \\
\text { environmental } \\
\text { attitude }\end{array}$ & $0.37^{*}$ & $0.43 * *$ & & & \\
\hline $\begin{array}{l}\text { Relative } \\
\text { importance of } \\
\text { AgGR }\end{array}$ & & $-1.482 * * *$ & $1.412 * *$ & $-1.82 * *$ & \\
\hline Existence values & $0.32 * * *$ & & & $-0.50 * * *$ & \\
\hline Use values & $0.38 * * *$ & & & $-0.39 * * *$ & \\
\hline $\begin{array}{l}\text { Citizen } \\
\text { responsibility }\end{array}$ & & $0.29 * * *$ & $0.21 * *$ & $-1.06 * * *$ & $-0.43^{* * *}$ \\
\hline $\begin{array}{l}\text { Consumer } \\
\text { responsibility }\end{array}$ & & $0.17 * *$ & & $-0.31 * *$ & $-0.38 * * *$ \\
\hline $\begin{array}{l}\text { Farmer } \\
\text { responsibility }\end{array}$ & $-0.16^{* *}$ & & & $0.27^{* *}$ & \\
\hline $\begin{array}{l}\text { Familiarity of } \\
\text { products }\end{array}$ & & & & & $-0.48 * *$ \\
\hline $\begin{array}{l}\text { Info use } \\
\text { (animals) > } \\
0.5 \text { min }\end{array}$ & & & & $-0.39 *$ & \\
\hline $\begin{array}{l}\text { Info use (plants) } \\
>0.5 \mathrm{~min}\end{array}$ & & $0.54 * * *$ & $-0.47^{* * *}$ & & \\
\hline Hasty response & & & $0.70^{*}$ & & $-1.08 * *$ \\
\hline $\mathrm{N}$ & 1088 & 1201 & 1098 & 1077 & 1199 \\
\hline Nagelkerke $R^{2}$ & 0.103 & 0.083 & 0.071 & 0.397 & 0.104 \\
\hline Chi-squared & 81.99 & 71.44 & 46.48 & 252.37 & 68.25 \\
\hline$p$-Value & 0.000 & 0.000 & 0.000 & 0.000 & 0.000 \\
\hline $\begin{array}{l}\text { Correctly } \\
\text { classified (cut } \\
0.5 \text { ) }\end{array}$ & 69.6 & 71.6 & 83.9 & 90.4 & 86.8 \\
\hline
\end{tabular}

Variables are significant at the *** $99 \%$ level, ** $95 \%$ level, * $90 \%$ level.

the conservation of native breeds and varieties in agriculture. However, there was considerable variation in preferences between citizen segments. Of the five identified groups, two groups covering over half of the respondents had a high interest in the conservation of native breeds and varieties. Respondents in one of the segments clearly preferred the current state of conservation to additional conservation efforts, while one group had a favorable attitude toward conservation if the expenses were on a low level, and respondents in one segment were supportive but wavering in their preferences. The respondent groups were identified based on their preferences for conservation, and they also differed with respect to the use of additional information, their response carefulness and the certainty of the stated WTP.
Table 8 | Annual willingness to pay (in $2009 €$ ) for attributes.

\begin{tabular}{|c|c|c|c|c|}
\hline & $\begin{array}{l}\text { Conditional } \\
\text { logit } \\
\text { model }\end{array}$ & $\begin{array}{c}\text { Latent } \\
\text { class } \\
\text { model, } \\
\text { Class } 2\end{array}$ & $\begin{array}{c}\text { Latent } \\
\text { class } \\
\text { model, } \\
\text { Class } 3\end{array}$ & $\begin{array}{c}\text { Latent } \\
\text { class } \\
\text { model, } \\
\text { Class } 5\end{array}$ \\
\hline Plants in bank (400) & - & - & - & 13 \\
\hline Plants in bank (500) & - & -15 & - & - \\
\hline Plants on farms (500) & 60 & 19 & 7 & - \\
\hline $\begin{array}{l}\text { Plants on farms } \\
(1000)\end{array}$ & 70 & - & - & - \\
\hline $\begin{array}{l}\text { Ornamental plants } \\
\text { (majority) inventoried } \\
\text { and in bank }\end{array}$ & 14 & - & - & - \\
\hline Goats in bank & 17 & 7 & 105 & 3 \\
\hline Horses in bank & 33 & 15 & - & 12 \\
\hline Chickens in bank & 20 & 7 & 104 & 3 \\
\hline $\begin{array}{l}3 \text { cattle breeds on } \\
\text { farms }\end{array}$ & 44 & 14 & 211 & 6 \\
\hline $\begin{array}{l}2 \text { sheep breeds on } \\
\text { farms }\end{array}$ & -15 & - & - & - \\
\hline
\end{tabular}

Similar to previous studies of consumer preferences on biodiversity (e.g., Hanley et al., 1995), we also found lexicographic preferences for conserving AgGR. Those were expressed by the largest group of respondents (27\%), as their interest in conservation was high regardless of the costs. Lexicographic choices can occur as a result of simplification if the respondent finds the choice task too difficult to handle or as a result of actual lexicographic preferences (Sælensminde, 2006). In our case, it is difficult to determine whether respondents exhibited lexicographic preferences because they wanted to simplify the choice tasks or because the differences in the attribute levels were large. Respondents in the group which exhibited lexicographic preferences were more certain about their preferences, which supports the phenomenon of actual lexicographic preferences as the reason for their choices. In addition, their positive perceptions concerning the existence and use values of genetic resources support the observation of actual lexicographic preferences.

Due to the preference structures, WTP estimates were only obtained for three respondent groups and some of the attributes. In those groups where the cost variable was significant and meaningful WTP estimates could thus be estimated, the marginal WTPs were considerably lower than the WTPs of the whole sample based on the conditional logit model. This implies that in the whole sample, the results were influenced by the groups that were insensitive to the costs of conservation.

Our results can be compared with those obtained by Zander et al. (2013), who assessed the economic value of conservation programs for two Italian cattle breeds using a choice experiment directed to citizens. Zander et al. (2013) also found preference heterogeneity for most of the attributes of the conservation programs, as well as differences in the sensitivity to the cost attribute. According to their findings, $85 \%$ of the respondents supported increased conservation, and the mean WTP was $90 €$ 
for conserving each breed. The present results can also be linked to previous results of heterogeneity among farmers using native breeds and varieties. Soini et al. (2012) identified a segment of production-oriented farmers among European cattle breeders that would benefit from increased subsidies for keeping native breeds on farms. If the subsidies were increased to correspond to citizens' WTP, it would help particularly this subsidy-dependent group of farmers.

As the survey was Internet-based, we were able to obtain information on the time used for obtaining additional information about plant and AnGR. These variables, combined with certainty, could partly explain the membership in the latent classes. However, similarly to $\mathrm{Hu}$ et al. (2009) and Vista et al. (2009), there were no clear tendencies for the use of information to be associated with a lower or higher WTP. Further research is, however, needed to clarify the associations between preferences, uncertainty and information acquisition in the case of genetic resources.

The results provide implications concerning how to direct the conservation policies for AgGR in Finland. The WTP estimates for the attributes of the conservation programmes indicated that the participants valued particularly in situ conservation in the case of PGR, which would also imply the existence of native plant varieties in the landscape. However, a moderate level of this in situ conservation would be sufficient, as the highest level increased the WTP only slightly. For the conservation of animal breeds, the results emphasize the importance of in situ conservation of cattle breeds. The weak support for the conservation of sheep breeds compared to cattle breeds was understandable, as Finnsheep breeds are less familiar to the public. However, the low, even negative, WTP for the conservation of sheep breeds is in contradiction with the importance of Finnsheep in breeding (e.g., Thomas, 2010). Ex situ conservation of those animal breeds that are at present insufficiently protected in gene banks was perceived as important, particularly the conservation of the genetic material of the Finnhorse.

Although the cost-effectiveness of AgGR conservation is casedependent, some previous studies have recommended ex situ conservation in gene banks as a less expensive, less vulnerable and less policy-sensitive method of conservation (Dulloo et al., 2010; Silversides et al., 2012). These cost-effectiveness considerations do not, however, take into account the additional benefits that may be associated with in situ conservation, such as the visibility of local breeds and varieties in the landscape or the opportunity to use local breed products. Thus, taking into account citizens' preferences for in situ and ex situ conservation and using cost-benefit analysis in policy evaluation may shift the priorities of agricultural genetic resource conservation policies.

In this study, the conservation policies were based on equal participation of all citizens, as the policy was financed with taxes. An alternative approach would be to apply market-based incentives, e.g., payments for environmental services (PES) for the conservation of genetic resources (McNeely, 2006; Wunder, 2007; Narloch et al., 2011). PES would imply that actors who are major users of the resources are involved in making and adapting rules for conservation markets. For future experiments of PES, our results of the citizen groups that are most interested provide information for identifying the interested parties for the markets of AgGR.

\section{REFERENCES}

Ahtiainen, H., and Pouta, E. (2011). The value of genetic resources in agriculture: a meta-analysis assessing existing knowledge and future research needs. Int. J. Biodivers. Sci. Ecosyst. Serv. Manage. 7, 27-38. doi: 10.1080/21513732.2011.593557

Berrens, R. P., Bohara, A. K., Jenkins-Smith, H. C., Silva, C. L., and Weimer, D. L. (2004). Information and effort in contingent valuation surveys: application to global climate change using national internet samples. J. Environ. Econ. Manage. 47, 331-363. doi: 10.1016/S0095-0696(03)00094-9

Birol, E., Smale, M., and Gyovai, Á. (2006). Using a choice experiment to estimate farmers' valuation of agrobiodiversity on hungarian small farms. Environ. Resour. Econ. 34, 439-469. doi: 10.1007/s10640-006-0009-9

Blomquist, G., and Whitehead, J. (1998). Resource quality information and validity of willingness to pay in contingent valuation. Resour. Energy Econ. 20, 179-196. doi: 10.1016/S0928-7655(97)00035-3

Boxall, C. P., and Adamowicz, L. W. (2002). Understanding heterogeneous preferences in random utility models: a latent class approach. Environ. Resour. Econ. 23, 421-446. doi: 10.1023/A:1021351721619

Brown, G. M. (1990). "Valuation of genetic resources," in The Preservation and Valuation of Biological Resources, eds G. H. Orians, G. M. Jr. Brown, W. E. Kunin, and J. E. Swierzbinski (Seattle, WA: University of Washington Press), 203-228.

Cameron, T. A., and Englin, J. (1997). Respondent experience and contingent valuation of environmental goods. J. Environ. Econ. Manage. 33, 296-313. doi: 10.1006/jeem.1997.0995

Drucker, A. G., Gomez, V., and Anderson, S. (2001). The economic valuation of farm animal genetic resources: a survey of available methods. Ecol. Econ. 36, 1-18. doi: 10.1016/S0921-8009(00)00242-1

Dulloo, M. E., Hunter, D., and Borelli, T. (2010). Ex situ and in situ conservation of agricultural biodiversity: major advances and research needs. Notulae Botanicae Horti Agrobotanici Cluj-Napoca 38, 123-135.

Evenson, R. E., Gollin, D., and Santaniello, V. (1998). "Introduction and overview: agricultural values of plant genetic resources," in Agricultural Values of Plant Genetic Resources, eds R. E. Evenson, D. Gollin, and V. Santaniello (Wallingford: CABI Publishing), 1-25.

FAO, (2007). The State of the World's Animal Genetic Resources for Food and Agriculture. Rome: Commission on Genetic Resources for Food and Agriculture, FAO.

FAO, (2010). The Second Report on the State of the World's Plant Genetic Resources for Food and Agriculture. Available online at: http://www.fao.org/docrep/013/ i1500e/i1500e.pdf [Accessed 11 October 2011].

Garrod, G., Ruto, E., Willis, K., and Powe, N. (2012). Heterogeneity of preferences for the benefits of environmental stewardship: a latent-class approach. Ecol. Econ. 76, 104-111. doi: 10.1016/j.ecolecon.2012.02.011

Grammatikopoulou, I., Pouta, E., Salmiovirta, M., and Soini, K. (2012). Heterogeneous preferences for agricultural landscape improvements in southern Finland. Landsc. Urban Plan. 107, 181-191. doi: 10.1016/j.landurbplan.2012.06.001

Hanley, N., Mourato, S., and Wright, R. E. (2001). Choice modelling approaches: a superior alternative for environmental valuation? J. Econ. Surv. 15, 435-462. doi: 10.1111/1467-6419.00145

Hanley, N., Spash, C., and Walker, L. (1995). Problems in valuing the benefits of biodiversity protection. Environ. Res. Econ. 5, 249-272. doi: 10.1007/BF00691519

Hu, W., Adamovicz, W. L., and Veerman, M. M. (2009). Consumers' preferences for GM food and voluntary information access: a simultaneous choice analysis. Can. J. Agri. Econ. 57, 241-267. doi: 10.1111/j.1744-7976.2009.01150.x

McFadden, D. (1974). "Conditional logit analysis of qualitative choice behaviour," in Frontiers in Econometrics, ed P. E. Zarembka (New York, NY: Academic Press), $105-142$.

McNeely, J. A. (2006). Using economic instruments to overcome obstacles to in situ conservation of biodiversity. Integr. Zool. 1, 25-31. doi: 10.1111/j.17494877.2006.00009.x

Narloch, U., Drucker, A., and Pascual, U. (2011). Payments for agrobiodiversity conservation services for sustained on-farm utilization of 
plant and animal genetic resources. Ecol. Econ. 70, 1837-1845. doi: 10.1016/j.ecolecon.2011.05.018

Oldfield, M. L. (1989). The Value of Conserving Genetic Resources. Sunderland, MA: Sinauer Associates Inc.

Omondi, I., Baltenweck, I., Drucker, A. G., Obare, G., and Zander, K. K. (2008). Valuing goat genetic resources: a pro-poor growth strategy in the Kenyan semiarid tropics. Trop. Anim. Health Prod. 40, 583-589. doi: 10.1007/s11250-0089137-2

Ouma, E., Abdulai, A., and Drucker, A. (2007). Measuring heterogeneous preferences for cattle traits among cattle-keeping households in East Africa. Am. J. Agric. Econ. 89, 1005-1019. doi: 10.1111/j.1467-8276.2007.01022.x

Rege, J. E. O., and Gibson, J. P. (2003). Animal genetic resources and economic development: issues in relation to economic valuation. Ecol. Econ. 45, 319-330. doi: 10.1016/S0921-8009(03)00087-9

Roessler, R., Drucker, A. G., Scarpa, R., Markemann, A., Lemke, U., Thuy, L. T., et al. (2008). Using choice experiments to assess smallholder farmers' preferences for pig breeding traits in different production systems in North-West Vietnam. Ecol. Econ. 66, 184-192. doi: 10.1016/j.ecolecon.2007.08.023

Rose, J. M., and Bliemer, M. C. J. (2009). Constructing efficient stated choice experimental designs. Trans. Rev. 29, 597-617. doi: 10.1080/01441640902827623

Sælensminde, K. (2006). Causes and consequences of lexicographic choices in stated choice studies. Ecol. Econ. 59, 331-340. doi: 10.1016/j.ecolecon.2005.11.001

Silversides, F. G., Purdy, P. H., and Blackburn, H. D. (2012). Comparative costs of programmes to conserve chicken genetic variation based on maintaining living populations or storinf cryopreserved material. Br. Poult. Sci. 53, 599-607. doi: 10.1080/00071668.2012.727383

Soini, K., Diaz, C., Gandini, G., de Haas, Y., Lilja, T., Martin-Collado, D., et al. (2012). Developing a typology for local cattle breed farmers in Europe. J. Anim. Breed. Genet. 129, 436-447. doi: 10.1111/j.1439-0388.2012.01009.x

Taloustutkimus. (2013). Internet Panel. Available online at: http://www.taloust utkimus.fi/in-english/products_services/internet_panel/ [Accessed 28 August 2013].

Thomas, D. L. (2010). Performance and utilization of Northern European shorttailed breeds of sheep and their crosses in North America: a review. Animal 4 1283-1296. doi: 10.1017/S1751731110000856
Tienhaara, A., Ahtiainen, H, and Pouta, E. (2014). "The consumer and citizen roles and motives in valuation of agricultural genetic resources in Finland," in Paper Presented in the 20th Annual Conference of the European Association of Environmental and Resource Economists (Toulouse). Available online at: http:// www.webmeets.com/EAERE/2013/m/viewpaper.asp?pid $=870$

Vista, A. B., Rosenberger, R. S., and Collins, A. R. (2009). If you provide, will they read it? Response time effects in a choice experiment. Can. J. Agri. Econ. 57, 365-377. doi: 10.1111/j.1744-7976.2009.01156.x

Wunder, S. (2007). The efficiency of payments for environmental services in tropical conservation. Conserv. Biol. 21, 48-58. doi: 10.1111/j.15231739.2006.00559.x

Zander, K., Signorello, G., De Salvo, M., Gandini, G., and Drucker, A. (2013). Assessing the total economic value of threatened livestock breeds in Italy: Implications for conservation policy. Ecol. Econ. 93, 219-229. doi: 10.1016/j. ecolecon.2013.06.002

Conflict of Interest Statement: The Guest Associate Juha Kantanen declares that, despite being affiliated to the same institution as the authors, the review process was handled objectively and no conflict of interest exists. The authors declare that the research was conducted in the absence of any commercial or financial relationships that could be construed as a potential conflict of interest.

Received: 29 September 2014; accepted: 01 December 2014; published online: 18 December 2014

Citation: Pouta E, Tienhaara A and Ahtiainen H (2014) Citizens' preferences for the conservation of agricultural genetic resources. Front. Genet. 5:440. doi: 10.3389/fgene. 2014.00440

This article was submitted to Livestock Genomics, a section of the journal Frontiers in Genetics.

Copyright (C) 2014 Pouta, Tienhaara and Ahtiainen. This is an open-access article distributed under the terms of the Creative Commons Attribution License (CC BY). The use, distribution or reproduction in other forums is permitted, provided the original author(s) or licensor are credited and that the original publication in this journal is cited, in accordance with accepted academic practice. No use, distribution or reproduction is permitted which does not comply with these terms. 